\title{
Mammadov Y.B.*
}

DOI: 10.25108/2304-1730-1749.iolr.2018.57.243-262

\section{Lodge false information about terrorism investigation of the interaction of the competent authorities in their characteristics}

\begin{abstract}
Law enforcement authorities of the Azerbaijan Republic, as well as other officers of law-enforcement bodies and investigators determine the cause of the crimes of a terrorist nature of the tasks facing the end lodge false information about terrorism and the investigation of the disclosure issue is relevant. The interrelation of the investigator with the search and investigation bodies is of crucial importance for such offenses.

Regardless of the form of joint investigative and investigative agencies' activities, they always act as independent bodies. The only possible combination of these bodies' joint activities is to coordinate their activities in a coordinated manner, to establish investigative and operational groups that will serve the common purpose, joint arrangements for the location of investigations and operations, mutual information exchange, investigative and operational search information.
\end{abstract}

Keywords: crime investigation; operational-search activity; communication; exchange of information.

Mutual communication in the investigation of alleged terrorism crimes is understood as a joint arrangement with the use of the methods and means available to each party, directed to a complex solution of common tasks by an independent organizational entity, in the manner prescribed by law [3, p. 137].

\footnotetext{
-Mammadov Yashar Bakhtiyar oglu -a dissertator of the Judicial Expertise Center of the Ministry of Justice (Azerbaijan). E-mail: cavid6455@mail.ru
} 
The need to interact with the subjects involved in the disclosure and investigation of alleged terrorism crimes is conditioned by the following basic conditions:

-Lodge false information about terrorism in the presence of the common tasks in the fight against crime;

- They used methods and objectives, as well as a lack of diversity of criminal procedure and search functions. Thus, the investigator is guided by the CPM of the Republic of Azerbaijan, while other investigative and other procedural acts are based on other laws, orders and instructions when operating the methods and means of operational search activity. This time is right to conduct an independent investigator search operations. Experts, on the other hand, apply methods and means of research of physical carriers (physical, chemical, mathematical, biological, etc.);

- The investigation of the criminal case on criminal procedure and legal significance of the diversity of the results of the detective-search activity in the process of the lodge false information about terrorism works. Thus, the investigation of the criminal case, the operational-search measures employees of operational information and procedural proven to be tested further as a result of the operation of the court in the implementation of investigators to get;

- Inconsistency between the subject of the information about the crime of informing about terrorism and the functions of the subject using this information. Thus, in many cases the course of implementation of the detective-search measures, which ended with information obtained by investigators working on the investigation. As a result of search operations and investigations in the process of organization and conducting of information (for example, information about the location of other participants in the crime or terrorist actions committed by the instruments, etc) to be used by investigators is gained. 
Subjects such as investigators, operational staff, specialists, and others are involved in the investigation of alleged terrorism crimes. Criminal, criminal procedural, administrative and legal norms and enforceable normative acts (internal orders, instructions, etc.) as the legal basis for the interaction between the parties.

During the investigation of alleged terrorism information, the interaction consists of the following steps:

- verification of signals of emergency incidents on terrorism before the operation (pre-investigation);

- starting a criminal case on operational inspection materials (if there are indications of a libel suspect of terrorism);

-specific lodge false information about terrorism related preliminary investigation of the criminal case.

Investigator, officer, specialist, and so on in the investigation into alleged false information about terrorism, the following principles should be based on the effectiveness of the interconnection:

- strict compliance with the provisions of laws and other normative-legal acts;

- compliance with confidentiality by all participants of the interaction in the course of co-operation;

- interrelated activities for the implementation of a single senior official;

- the most appropriate use for different types and forms of cooperation;

- fighting against terrorism and ensuring the personal security of persons involved in the process of interaction relevant executive power bodies. This approach leads to tragic consequences, the destruction of evidence of negligence requirements and etc;

- planning of interaction between the subjects' functions, their powers and individual responsibilities during concrete investigative actions and tactical operations; 
- providing a leading role of the investigator when conducting a communication on a criminal case during investigation and prosecution of members of the investigative group on the crime of knowingly false information about terrorism;

- lodge false information about terrorism investigations of crimes involving various organs of the relationship between the start of the selection in terms of efficiency and completion of the appropriate time;

- complex application of technical, criminal and operational-technical means.

Certain conditions must be observed in order to ensure the effectiveness of interaction in the investigation of allegedly false information about terrorism. These include:

- interaction of each specific person or entity related to a joint discussion of the case in question involved in the initiative;

- in the course of these discussions, procedural and service regardless of the state of the relationship of equality of all participants;

- the joint resolution adopted on the subject of (members of the group or entity) independence in the implementation of these decisions every interaction;

- providing necessary assistance to each other process participants in the interaction.

View, any interaction of each party is closely associated with the activity at the proper level and effectiveness of taking part in this process [4, p. 104]. The main methods of such activity can be summarized as follows:

- the deep knowledge of the criminalistics character of criminal murders on terrorism, the organization of preliminary investigation of these crimes, the tactics of carrying out necessary investigative actions and operational search measures, the ability to apply technical criminalistics methods and means; 
- information about the (suspect caught in the act of crime, illegal arms storage and destruction of the terrorist organization, the head of being compromised) general purpose of this activity in the process of interaction;

- every interaction participant in the presence of a high sense of responsibility.

It would be important to note that the results of the interaction should be evaluated not only by the number of joint sessions but also by the quality of the joint arrangements implemented real. Article 6 of the Law of the Republic of Azerbaijan "On Combating Terrorism" provides for the use of knowingly false information about terrorism, the state bodies responsible for fighting terrorism in general (Article 6): "State and local self-governing bodies, irrespective of their form of ownership, organizations, public associations, officials and citizens are obliged to assist the state bodies fighting terrorism. "This, in turn, causes the interaction with the relevant bodies of executive power, fighting against terrorism, other legal entities and individuals.

Anti-terrorism center of the CIS is of great importance in the fight against terrorism, including the opening and investigation of crimes of this category. This center ensures the interaction of states, ministries, enterprises and public organizations against terrorism in the CIS territory within their competence [2, p. $121]$.

Interaction between law enforcement and investigative and investigative agencies is based on the mutual relationship and dependence of investigative actions and operational search activities when dealing with issues related to the disclosure, investigation and prevention of offenses [1].This or other investigative action is necessary at a certain stage of the investigation of information obtained during the performance of investigative actions. At the same time, the collection of evidence on that criminal case may in turn require the conduct of operationalsearch actions. This creates a basis for interaction between investigative and operational-search agencies. 
The provisions of the Criminal Procedural Law do not include the term "mutual action" that covers the mutual activity of the investigating and prosecutorial bodies and the general provisions of the investigation. However, in the relevant articles of the law, the essence of the activities entrusted to these bodies was successfully opened during the investigation, investigation and prosecution of crimes.

The legal basis of the interaction between investigative and operational divisions is regulated by the Constitution of the Republic of Azerbaijan, the Criminal and Criminal Procedure Code of the Republic of Azerbaijan, the Law on Detective-Investigative Activities, the Criminal Code and etc.).

Procedural attitudes of investigative and operational (inquiry) bodies may be all the cases that are subject to an initial investigation. The investigative body shall conduct the investigative actions not later than ten days after the commencement of the criminal case and give the case to the investigator, and the operational search and investigation (investigative) bodies shall investigate the offense, continue to see and inform the investigator about the consequences [5, p. 42].

All activities of the search and investigation bodies should not be contrary to the rules of the criminal procedure law, but should not be contrary to them. Further strengthening of the interaction of the investigative and operational agencies with the provisions of the criminal procedure legislation creates conditions for the commission of crimes in the shortest possible time, with less power and resources. Forms of interaction can be different. Their classification is mainly related to the two main aspects: the nature of the activity carried out by the investigative body on the investigator's instruction and the duration of the interaction.

In accordance with the CPC of the Republic of Azerbaijan, the forms of interaction between the investigation and operational (inquiry) bodies during the investigation of crimes include: 
- providing methodological assistance to investigative divisions on criminallaw and criminal-procedural aspects of operational-search activities until the operational units are completed before the opening of operational-registration works (TPCs);

- performing joint activities when considering physical, legal (official) persons, as well as mass media about committed or committed crimes;

- operational warranty for criminal cases prior to the commencement of their investigation (from the moment of their adjudication);

- activity based on a joint plan drawn up by criminal proceedings;

- fulfillment of the investigator's instructions and instructions on conducting investigative actions by the operational-search agency;

- fulfillment of the instructions and instructions of the investigative body of the investigator on the conduct of search actions;

- assisting the investigator (s) of the operational (inquiry) body to carry out separate investigative actions (inspection, search, verification of the place of the test, etc.);

- activity agreed upon in the conduct of operational search actions and investigative actions on the basis of inquiries of the relevant authorities of foreign countries, in accordance with the agreements signed by the Republic of Azerbaijan on rendering legal assistance.

Mutual cases of terrorism are also distinguished by the duration of the interrogation process: once, periodically and permanently (prior to the completion of the preliminary investigation). Interaction between investigative and operational agencies is also distinguished from procedural and organizational aspects [7, p. 9093]. The procedural aspect of mutual activity is:

- detecting the signs of a crime which is subject to pretrial investigation, prompt investigation of the case by the investigative body to determine and strengthen the traces of the crime, and to give the case to the investigator; 
- giving the investigator materials, which are signs of the crime, obtained through operational search measures to resolve the issue of initiation of a criminal case;

- assisting the investigator in the conduct of separate investigative actions by the operational-investigative body;

- assisting the investigator in the conduct of separate investigative actions by the operational-investigative body;

- fulfillment of the investigator's instructions to conduct a separate investigation or search activity by the operational-search agency;

- exchange of information obtained as a result of investigative actions and operational search measures.

The investigator shall have the right to charge the investigative-apparatus of the inquiry into the conduct of investigative and search actions related to knowingly false information about the terrorism committed and to assist him during the proceedings. The investigative body shall be obliged to execute the investigator's instruction [6, p. 601].

One of the forms of interaction between the investigation and search and investigation bodies is the exchange of information obtained as a result of procedural activities and operational search activities. Mutual exchange of information obtained as a result of investigative actions and operational search activities shall determine the main directions of further investigation of the investigative and investigative bodies. Therefore, the information received must be discussed together and the necessary measures are to be taken for their verification, based on which information should be drawn up for an investigation and operational search action plan.

From the foregoing, it can be concluded that a decision on the separation of a group of operational staff (or decision-making on the establishment of an 
investigation group) to assist the investigator in investigating and prosecuting alleged terrorist offenses is fully justified conditions.

\section{References}

1. The scope of the offenses referred to the competence of the law-enforcement authorities of the Republic of Azerbaijan is indicated in the relevant decrees of the President of the Republic of Azerbaijan dated August 25, 2001 and October 27, 2001, May 27, 2002 (in Azerbaijani).

2. Aliyev B. A. Dini ekstremizm terror fealiyyatinin tehlukeli menbeyidir [Religious extremism is a dangerous source of terrorist activity] // Sivilizasiya ve terror (meqaleler toplusu) [Civilization and terrorism (collection of articles)]. Baku, 2002, pp. 113-127.

3. Artamonov I.I. Terrorizm: sposoby predotvrascheniya, metodika rassledovaniya [Terrorism: methods of prevention, investigation methods]. Biblioteka operativnika [Library of the operative officer (open stock)]. Moscow, 2002, 332 p.

4. Galakhov S.S. Kriminal'nye vzryvy. Osnovy operativno-rozysknoyi deyatel'nosti po bor'be s prestupleniyami terroristicheskogo kharaktera [Criminal explosions. Fundamentals of operational-search activities to combat crimes of a terrorist nature]. Moscow, 2002, p. 104-105.

5. Kustov A.M. Model' mekhanizma terroristichekoyi deyatel'nosti prestupnoyi gruppirovki [Model of the mechanism of terrorist activity of a criminal gang] // Antiterror, Stavropol, 2002, no.1, 147 p.

6. Obraztsov V.A, Toporkov A.A. Ustanovlenie litsa sovershivshego prestuplenie $\mathrm{v}$ usloviyakh neochevidnosti [Establishment of a person who committed a crime under conditions of impartiality] // Kriminalistika pod red. V.A. Obraztsova [Criminalistics ed. V.A. Obraztsov]. Moscow, 2001, 770 p. 
7. Us O.V. Criminal and legal estimation of behaviour of person / Науковий вісник Міжнародного гуманітарного університету. Серія: «Юриспруденція» [Scientific Herald of International Humanitarian University. Serial: Jurisprudence]. Issue no. 32, 2018, pp. 90-93. 